\title{
Selecting Target Antigens for Cancer Vaccine Development
}

\author{
Luigi Buonaguro and Maria Tagliamonte *
}

Laboratory of Innovative Immunological Models, Istituto Nazionale per lo Studio e la Cura dei Tumori,

"Fondazione Pascale"_-IRCCS, 80131 Naples, Italy; 1.buonaguro@istitutotumori.na.it

* Correspondence: m.tagliamonte@istitutotumori.na.it; Tel.: +39-081-5903.624

Received: 25 September 2020; Accepted: 13 October 2020; Published: 17 October 2020

\begin{abstract}
One of the principal goals of cancer immunotherapy is the development of efficient therapeutic cancer vaccines that are able to elicit an effector as well as memory $\mathrm{T}$ cell response specific to tumor antigens. In recent years, the attention has been focused on the personalization of cancer vaccines. However, the efficacy of therapeutic cancer vaccines is still disappointing despite the large number of vaccine strategies targeting different tumors that have been evaluated in recent years. While the preclinical data have frequently shown encouraging results, clinical trials have not provided satisfactory data to date. The main reason for such failures is the complexity of identifying specific target tumor antigens that should be unique or overexpressed only by the tumor cells compared to normal cells. Most of the tumor antigens included in cancer vaccines are non-mutated overexpressed self-antigens, eliciting mainly $\mathrm{T}$ cells with low-affinity $\mathrm{T}$ cell receptors (TCR) unable to mediate an effective anti-tumor response. In this review, the target tumor antigens employed in recent years in the development of therapeutic cancer vaccine strategies are described, along with potential new classes of tumor antigens such as the human endogenous retroviral elements (HERVs), unconventional antigens, and/or heteroclitic peptides.
\end{abstract}

Keywords: tumor antigens; cancer vaccines; heteroclitic peptides

\section{Introduction}

Preventive vaccines were originally developed to elicit an antigen-specific memory immunity in healthy subjects that is able to promptly react to subsequent infections by pathogens that could occur during the lifetime. Conversely, cancer vaccines are a therapeutic strategy aimed at eliciting a specific de novo immune response against tumor antigens or amplifying an existing anti-tumor immune response. Therefore, in addition to a memory immunity, such vaccines are intended to elicit a potent anti-cancer effector immune response. This mechanism involves the professional antigen-presenting cells (APCs) for triggering a cytotoxic effector $\mathrm{CD} 8^{+} \mathrm{T}$-cell (CTL) response.

Several therapeutic cancer vaccine strategies and formulations have been evaluated in recent years in different tumor settings involving thousands of cancer patients. However, only modest effects have been reported at a low rate (less than $7 \%$ ) and an overall rate of clinical benefit of around 20\% [1-4]. The only FDA-approved therapeutic cancer vaccine to date is Provenge ${ }^{\circledR}$ for patients with castration-resistant prostate cancer, which showed a limited 4.5-month improvement in overall survival (OS) compared to the placebo [5,6].

Such limited efficacy may be ascribed to two main factors: the immunosuppressive factors infiltrating the tumor microenvironment (TME) and the specificity of target tumor antigens included in the vaccine formulation. While the first factor can be addressed by designing strategies combining cancer vaccines and other immunotherapies [7-11], the latter requires the identification of novel tumor-specific antigens able to elicit effective and specific anti-tumor responses $[12,13]$. Tumor antigens need to be 
sufficiently distinct from self-antigens to break the immunological tolerance that physiologically blocks undesired auto-immune reactivity against normal cells.

In the present review, target tumor antigens employed in recent years in the development of therapeutic cancer vaccine strategies are described, together with potential new classes of tumor antigens, such as the human endogenous retroviral elements (HERVs), as unconventional antigens and/or heteroclitic peptides.

\section{Tumor Antigens}

Cancer vaccines are based on tumor antigens expressed in the context of Major Histocompatibility Complex (MHC) molecules able to elicit a strong tumor-specific CTL response, which may result in the killing of tumor cells and cancer regression.

Early cancer vaccines were based on approaches aimed at targeting the broadest antigen repertoire to avoid selection of escape variants. These included autologous tumor lysates, whole tumor-derived mRNA, irradiated autologous tumor cells, or allogeneic tumor cell lines, and have been evaluated in several clinical trials targeting different tumor types $[14,15]$. However, these approaches have several limitations, such as the need for a sufficient amount of tumor specimen, their collection and formulation, and challenges in terms of logistics and standardization of regulatory demands, including Good Manufacturing Practice (GMP) requirements. One of the most problematic aspects is related to the overwhelming number of non-tumor self-antigens in the whole tumor cell preparation, which not only dilutes the number of tumor-specific antigens but also induces an immunological tolerance [16]. To overcome such limitations, in recent years, therapeutic cancer vaccines are mostly based on one or a restricted number of cancer antigens. Tumor antigens can be classified into tumor-associated antigens (TAAs) and tumor-specific antigens (TSAs). In particular, TSAs are considered more effective than TAAs in cancer immunotherapy because they are the only cancer-specific targets unique to cancer cells, deriving either from viral antigens or from tumor-specific genomic mutations [17].

\subsection{Tumor-Associated Antigens (TAAs)}

Cancer cells, as result of their malignant profile, can constitutively overexpress antigens derived from protein, which are mainly involved in the replication and/or migration of the cancer cells. The antigens derived from the aberrantly overexpressed self-antigens in tumor cells compared to normal cells (e.g., RAGE-1, hTERT, HER2, mesothelin, and MUC-1) are defined as tumor-associated antigens (TAAs) and might represent universal antigens among patients with the same malignancy [18-21]. Besides the overexpressed antigens, TAAs can include: cell lineage differentiation antigens, which are normally not expressed in adult tissue (e.g., tyrosinase, gp100, MART-1, prostate-specific antigen (PSA); prostatic acid phosphatase (PAP)) [22-24]; and cancer/germline antigens (also known as cancer/testis), which are normally expressed only in immune privileged germline cells (e.g., MAGE-A1, MAGE-A3, NY-ESO-1, and PRAME) [25-29].

Overexpressed and tissue differentiation antigens are able to induce an antitumor immune response when high levels of expression of these proteins reach the threshold for $\mathrm{T}$ cell recognition, breaking immunological tolerance. However, the main drawback with using TAAs in cancer immunotherapy is the potential induction of autoimmunity against the corresponding normal tissues [30,31]. As these antigens are also expressed in healthy tissue as self-antigens, they are generally characterized by low immunogenicity, and $\mathrm{T}$ cells have low affinity receptors (TCR), which are unable to mediate effective anti-tumor responses [32]. Additionally, T cells that recognize these antigens may be removed from the immune repertoire by central and peripheral tolerance [33]. The formulation with an effective adjuvant may overcome the problem, significantly increasing the immunogenicity of the antigens and resulting in a clinical benefit for cancer patients.

Cancer germline/cancer testis antigens (CTAs) are tumor-associated antigens expressed only in human tumors of different histological origins but not in somatic normal tissue, except for testis and placenta tissue [34]. In this respect, CTAs have been considered promising targets for 
immunotherapy approaches thanks to their tumor-specificity and strong immunogenicity for the absence of immune tolerance.

\section{TAA-Based Clinical Trials}

Several therapeutic cancer vaccines based on TAAs have been evaluated in different phases of clinical trials addressing diverse malignancies. However, the induction of a strong CTL response has shown poor correlation with a favorable clinical outcome in several malignancies $[35,36]$. This may be due to different reasons, including the low affinity between the TCR and the antigens, the tumor evasion with loss of tumor antigen expression, and the inhibition of the cytotoxic activity in the immunosuppressive tumor environment.

Several clinical trials have been and are currently being conducted to assess the safety and immunogenicity of therapeutic cancer vaccines based on TAAs in different cancer settings [13]. In this respect, our group has coordinated a Phase I/II clinical trial assessing the safety and immunogenicity of a novel therapeutic cancer vaccine approach for Hepatocellular carcinoma (HCC) based on naturally processed and presented wild-type tumor-associated antigens (TAAs) (HepaVac-101 clinical trial, EudraCT Nr. 2015-003389-10) [37,38]. Of all these therapeutic cancer vaccine early-stage clinical trials, only five have been moved forward to Phase III efficacy trials and have been completed. Of these, only three have enrolled a sufficient number of patients to generate significant publishable data with limited efficacy (Table 1).

Table 1. Cancer vaccines in Phase III completed based on tumor-associated antigens (TAAs).

\begin{tabular}{cccccc}
\hline Tumor & Peptide Vaccine & Status & Phases & NCT Number & Ref. \\
\hline Breast Cancer & Nelipepimut-S (NP-S) & Completed & Phase 3 & NCT01479244 & {$[39]$} \\
\hline Metastatic Melanoma & MDX-1379 (gp100) & Completed & Phase 3 & NCT00094653 & {$[40]$} \\
\cline { 2 - 6 } & gp100 & Completed & Phase 3 & NCT00019682 & {$[41]$} \\
\hline Multiple Myeloma & MAGE-A3/NY-ESO-1 & Completed & Phase 2/Phase 3 & NCT00090493 & N.A. \\
\hline Esophageal Cancer/Gastric Cancer & G17DT & Completed & Phase 3 & NCT00020787 & N.A. \\
\hline
\end{tabular}

The trial evaluating the efficacy of Nelipepimut-S(NP-S) antigen in preventing breast cancer recurrence showed no serious adverse events (SAEs) and no significant between-arms differences in disease-free survival (DFS) events at the median follow-up (16.8 months). In the NP-S arm, however, imaging detected $54.1 \%$ of recurrence events in asymptomatic patients versus $29.2 \%$ in the placebo $\operatorname{arm}(p=0.069)$, contributing to early trial termination [39].

The trial comparing the gp100 vaccine alone vs. the combination with Ipilimumab in patients with metastatic melanoma showed that the vaccine did not improve the overall survival as compared to Ipilimumab alone [40].

Finally, a clinical trial evaluated the efficacy of the gp100 combined with high-dose interleukin-2 (IL-2) in patients with metastatic melanoma. Although the experimental arm treated only with the gp100 vaccine was missing, the results showed that the vaccine provided an improved overall clinical response as well as longer progression-free survival compared to the immune-activating agent IL-2 alone [41].

\subsection{Tumor-Specific Antigens (TSAs)}

The limited results obtained with cancer vaccines based on TAAs urged the development of new strategies, in particular, the identification of different types of target antigens. Tumor-specific antigens (TSAs) are strictly specific to tumors not expressed on the surface of normal cells and include mutated neoantigens as well as antigens from oncoviruses, endogenous retroviral elements (HERVs), and unconventional antigens $[17,42,43]$.

Mutated neoantigens are personalized antigens arising from cancer-related nonsynonymous mutations or other genetic alterations resulting in mutated peptides presented by HLA on the tumor cell surface of the immune system. Cancers are characterized by accumulation of genetic and epigenetic 
alterations in somatic cells with selective growth advantage to cancer cells. Driver mutations are therefore positively selected during the evolution of the cancer and cannot be lost because they are often required for maintenance of the final cancer. A direct consequence is the possible mutation of protein sequences and presentation of mutated antigens in the human leucocyte antigen-1 (HLA-I) complex on the tumor surface, different from the germline. Consequently, a specific and effective $\mathrm{T}$ cell response against cancer cells is triggered and not subject to central and peripheral immune tolerance [44]. The relevance of the mutated neoantigens in eliciting a potent anti-tumor $\mathrm{T}$ cell response is supported by several studies showing that response to the immune checkpoint inhibitors (ICI) often correlates with high tumor mutation load, which leads to a high number of mutated neoantigens [45].

RNA-sequencing (RNA-seq) data from The Cancer Genome Atlas (TCGA) from thousands of tumor samples show that the number of neoantigens per tumor type correlates positively with a gene expression signature of $\mathrm{T}$ cell cytolytic activity [43]. In particular, analysis of whole-exome sequencing of 619 colorectal cancers showed that high neoantigen load is associated with increased numbers of TILs and improved survival [46].

However, contradictory results have been recently reported about the correlation of the neoantigen load with the patients' survival in other tumors [47-50]. In a recent study, we showed that neither the Tumor Mutational Burden (TMB) nor the number or the quality of the predicted neoantigens are associated with a prolonged survival in HCC patients not undergoing immunotherapy treatment. This contrasts results in melanoma and lung cancer patients undergoing immunotherapy [51,52]. These contradictory results might be due to the small number of mutations and low neoepitope load in HCC patients [53].

The major limitation of cancer vaccines based on mutated neoantigens is that they are strictly individual (private), and their identification requires a combination of high-throughput genomics, proteomics, and immunomics screening procedures, which currently cannot be applied on a large scale. Moreover, the efficacy of such a highly-personalized approach is possibly reduced by the high mutational rate of tumors, which drives a constant generation of new target mutated neoantigens and a consequent cancer immune evasion.

\section{TSAs-Based Clinical Trials}

Several clinical trials based on mutated neoantigens are currently ongoing in Phase I or Phase I/II, targeting a variety of cancer types (Table 2). Results have been published only from three clinical trials, and they all show the feasibility and safety of the strategy. In particular, melanoma patients treated with patient-specific mutated neoantigens responded to vaccination, discriminating between wild-type and mutated antigens. Vaccinated patients showed significantly delayed tumor recurrence and experienced complete tumor regression after anti-programmed cell death-1 (anti-PD-1) therapy, with the expansion of the repertoire of neoantigen-specific T cells [54-56]. The same approach applied to patients affected by glioblastoma showed safety and immunogenicity [57].

Feasibility and immunogenicity were confirmed in other recently completed clinical trials targeting different solid tumors [58], small cell of lung carcinoma (SCLC) [59], as well as melanoma [60].

Table 2. Cancer vaccines in Phase I/II based on tumor-specific antigens (TSAs).

\begin{tabular}{cccc}
\hline Tumor & Status & Phases & NCT Number \\
\hline ALL & Active, not recruiting & Phase 1|Phase 2 & NCT03559413 \\
\hline Breast Cancer & Recruiting & Phase 1 & NCT04105582 \\
\hline Fibrolamellar HCC & Recruiting & Phase 1 & NCT04248569 \\
\hline Follicular Lymphoma & Not yet recruiting & Phase 1 & NCT03361852 \\
\hline Gastric Cancers & Recruiting & Not Applicable & NCT03468244 \\
\hline
\end{tabular}


Table 2. Cont

\begin{tabular}{|c|c|c|c|}
\hline Tumor & Status & Phases & NCT Number \\
\hline \multirow{4}{*}{ Glioblastoma } & Recruiting & Phase 1 & NCT04015700 \\
\hline & Active, not recruiting & Phase 1 & NCT03422094 \\
\hline & Recruiting & Phase 1 & NCT02287428 \\
\hline & Completed & Phase 1 & NCT02149225 \\
\hline \multirow{2}{*}{ HCC } & Recruiting & Phase 1|Phase 2 & NCT04251117 \\
\hline & Recruiting & Phase 1 & NCT03674073 \\
\hline Kidney Cancer & Recruiting & Phase 1 & NCT02950766 \\
\hline Lymphocytic Leukemia & Not yet recruiting & Phase 1 & NCT03219450 \\
\hline \multirow{6}{*}{ Melanoma } & Not yet recruiting & Phase 1|Phase 2 & NCT04364230 \\
\hline & Recruiting & Phase 1 & NCT04072900 \\
\hline & Not yet recruiting & Phase 1 & NCT03929029 \\
\hline & Active, not recruiting & Phase 2 & NCT02129075 \\
\hline & Completed & Phase 1 & NCT02035956 \\
\hline & Active, not recruiting & Phase 1 & NCT01970358 \\
\hline \multirow{9}{*}{ Multiple Cancers } & Recruiting & Phase 1 & NCT04147078 \\
\hline & Recruiting & Phase 1 & NCT03956056 \\
\hline & Recruiting & Phase 1|Phase 2 & NCT03953235 \\
\hline & Not yet recruiting & Not Applicable & NCT03908671 \\
\hline & Active, not recruiting & Phase 1 & NCT03662815 \\
\hline & Recruiting & Phase 1|Phase 2 & NCT03639714 \\
\hline & Recruiting & Phase 1 & NCT03568058 \\
\hline & Recruiting & Phase 1 & NCT04087252 \\
\hline & Recruiting & Phase 1 & NCT03552718 \\
\hline \multirow{4}{*}{ NSCLC } & Recruiting & Phase 1 & NCT04078269 \\
\hline & Not yet recruiting & Phase 1 & NCT03871205 \\
\hline & Recruiting & Phase 1 & NCT04487093 \\
\hline & Recruiting & Phase 1 & NCT04397926 \\
\hline Ovarian Cancer & Not yet recruiting & Phase 1 & NCT04024878 \\
\hline \multirow{4}{*}{ Pancreatic Cancer } & Recruiting & Phase 1 & NCT04161755 \\
\hline & Recruiting & Phase 1 & NCT03645148 \\
\hline & Active, not recruiting & Phase 1 & NCT03122106 \\
\hline & Recruiting & Phase 1 & NCT03558945 \\
\hline \multirow{2}{*}{ Pediatric Brain Tumor } & Not yet recruiting & Phase 1 & NCT03988283 \\
\hline & Not yet recruiting & Phase 1 & NCT03068832 \\
\hline Prostate Cancer & Recruiting & Phase 1 & NCT03532217 \\
\hline \multirow{2}{*}{ SCLC/NSCLC } & Not yet recruiting & Phase 2 & NCT04397003 \\
\hline & Not yet recruiting & Phase 1 & NCT04266730 \\
\hline SPCM & Recruiting & Early Phase 1 & NCT03631043 \\
\hline TNBC & Recruiting & Phase 1 & NCT03199040 \\
\hline UBC & Recruiting & Phase 1 & NCT03359239 \\
\hline
\end{tabular}

ALL, acute lymphoblastic leukemia; HCC, hepatocellular carcinoma; NSCLC, non-small cell lung cancer; SCLC, small cell lung cancer; SPCM, smoldering plasma cell myeloma; TNBC, triple-negative breast carcinoma; UBC, urothelial/bladder cancer. 


\subsection{Human Endogenous Retroviral Elements (HERVs) as Target Antigens}

Human endogenous retroviral elements (HERVs) constitute $8 \%$ of the human genome and derive from the chromosomal integration of retroviral RNAs upon germline infections [61].

In cancer, transcription of HERVs is induced and activated upon malignant transformation and/or epigenetic therapy, such as DNA methyltransferase inhibitors (DNMTi) and histone deacetylase inhibitors (HDACi), becoming potential targets for cancer therapeutic approaches [62-64]. The combination of epigenetic therapies may be very effective in eliciting a strong and robust expression of a wide range of Endogenous retroviral elements (ERVs) and may induce the expression of ERV LTRs located within genes that then act as novel promoters generating novel transcripts [65].

Activation of the HERVs can lead to a state of viral mimicry, inducing an innate immune response and leading to production of type I and type III interferon and other cytokines [66,67]. By mimicking viral infections, ERVs could function as an intrinsic adjuvant, possibly sensitizing cancer cells for immune recognition [68]. One of the consequences of activated interferon signaling is the transcriptional induction of antigen presentation machinery, including the major histocompatibility complex (MHC) class I alleles and the transporter involved in antigen processing 1 (TAP1) [69,70].

All these events lead to the generation of a novel pool of tumor-specific antigens identified in different tumor types that can be exploited as T cell targets on tumor cells [62]. HERV-derived antigens have been used to develop cancer vaccines and chimeric antigen receptor (CAR)-expressing $T$ cells, which have been tested only in a pre-clinical setting to date [71-76]. Altogether, these pre-clinical studies show the safety, immunogenicity, and preliminary efficacy data, but none of these strategies have been tested in human clinical trials so far.

\subsection{Unconventional Antigens}

The identification of tumor antigens relies on the proteome sequencing by high-throughput LC-MS/MS analysis [77]. However, proteomics data from MS/MS spectra are interpreted using reference protein sequence databases and cannot be used to identify any novel cancer-specific sequences [78]. Therefore, only a strategy combining proteomics and genomics data from the same tumor lesion (i.e., proteogenomic) can enable the identification of tumor-specific peptides that are missing from the reference databases $[79,80]$.

Identification of mutated neoantigens can significantly benefit from direct detection using proteogenomics [81]. Somatic mutations as well as gene fusions have been identified in colorectal [82], breast [83,84], ovarian [85], and liver cancers [86]. However, such a combined approach shows major potency in the identification of unconventional antigens, which otherwise would be difficult to prove. The proteasomes may generate peptide splice variants, splicing two peptide fragments together, significantly increasing the number of Human leukocyte antigen (HLA) ligands [87,88].

Strikingly, a single spliced peptide can arise from non-consecutive sequences even across multiple genes, leading to a great diversity of displayed HLA ligands, whose contribution to cancer immunology yet remains elusive $[89,90]$.

Proteogenomics enables the identification of the proteome deriving from non-coding or unannotated RNAs. Several long non-coding RNAs can be translated by ribosomes into short proteic sequences, providing a potential source of HLA ligands [91,92]

Cancer-specific MHC class I antigens derived from the non-coding region have been described and proven to elicit anti-cancer CTL responses in mouse cancer models [93]. Unlike mutated neoantigens that arise from passenger mutations, non-coding RNA antigens are detected across individuals and may serve as attractive targets of vaccination or adoptive $\mathrm{T}$ cell transfer therapy [94].

\section{Optimizing Antigenic Targets}

To improve the immunogenicity of tumor antigens, mainly the TAAs, to be included in cancer vaccine formulations, peptides can be modified to increase their affinity and binding to the present 
MHC-I [95]. Such modified peptides (heteroclitic peptides) have been shown to break the immunological tolerance, inducing a more potent $\mathrm{CD} 8^{+} \mathrm{T}$ cell response able to recognize the native peptide expressed on the tumor cells and kill them [96-100]. The low affinity between the T cell receptor (TCR) and the peptide-major histocompatibility complex (pMHC) would allow the TCR to cross-react with multiple pMHCs [101-103].

\subsection{Heteroclitic Peptides Improving Binding to MHC-I}

Most of the studies have described an improvement of the CD8 ${ }^{+} \mathrm{T}$ cell response modifying the amino acid residues in the anchor positions interacting with the HLA molecule [99,100,104,105].

A peptide derived from gp100, a lineage differentiation antigen identified in melanoma, has been modified (heteroclitic) to optimize its bind to MHC complex. This modified peptide, gp100:209-217(210 M), binds with a higher affinity to HLA-A2 than the corresponding wt peptide and stimulates a specific and better $\mathrm{T}$ cell response in vitro and in vivo [97]. Clinical trials based on vaccination with $210 \mathrm{M}$ antigen, alone or in combination with interleukin-2 (IL-2), have demonstrated the induction of peptide- and tumor-specific cytotoxic T-lymphocyte responses in peripheral blood [106,107]. In particular, a randomized phase III clinical trial, based on $210 \mathrm{M}$ peptide vaccine, showed that in the group treated with gp100 peptide vaccine followed by high-dose interleukin-2, the response rate was higher and progression-free survival longer than in group treated with interleukin-2 alone [41].

Another modified peptide, CAP1-6D, an epitope of CEA, has been modified to improve the binding to MHC-I complex and has been shown to trigger a more potent CTL response, and T cells activated have been shown to be cross-reactive with wild-type CAP1 and to recognize CEA+ HLA-A2+ tumor cells [108,109].

\subsection{Heteroclitic Peptides Improving Binding to TCR}

An alternative approach for improving the immunogenicity of natural TAAs is to generate heteroclitic peptides with mutations in the TCR-binding residues to break the immunological tolerance and induce a more potent $\mathrm{CD}^{+} \mathrm{T}$ cell response $[110,111]$. Heteroclitic peptides modified in the TCR-binding residues of melanoma specific Trp2 TAA have been shown to improve the control of tumor growth [112]. Preliminary results from our group showed that recognition of a wild-type (WT) epitope by Peripheral blood mononuclear cells (PBMCs) can be significantly improved by modifying the TCR-facing amino acids, in particular at the P4 residue, of the HPV E7 WT epitope expressed on TC1 mouse lung tumor cell lines. Bioinformatics prediction algorithms identified specific amino acid substitutions at the P3 and P4 residues of the epitope, resulting in an increased affinity of the WT peptide to the $\mathrm{H}-2-\mathrm{Db}$ allele. Moreover, heteroclitic peptides with amino acid changes in one of the TCR-facing and anchor position residues elicit an even stronger immune response, cross-reacting with the parental wild-type peptide. CTL elicited by the heteroclitic peptides show potent lytic activity on target cells expressing the WT peptide as well as control of tumor growth in vivo (in press).

\section{Conclusions}

Cancer immunotherapy has experienced tremendous progress in the last decade, including the dramatic expansion of our understanding of how cancer cells evade the immune system, and the development of several new therapies that are benefitting cancer patients.

Therapeutic cancer vaccines offer an attractive alternative immunotherapy because of their potential safety, specificity, and long-lasting response due to stimulation of immune memory.

Unfortunately, many previous attempts to develop effective therapeutic cancer vaccines yielded disappointing results. Tumor antigens used so far all suffer from major drawbacks. TAAs suffer from expression on normal cells and immunological tolerance, which can be overcome by designing appropriate heteroclitic epitopes. TSAs represent the optimal target antigens but suffer from patient specificity, which hampers exploitation on a large scale. Unconventional antigens may represent a great advancement, and their efficacy needs to be proven in clinical trials (Figure 1). The accurate 
evaluation of the previous failures, combined with the constant technological improvements, will lead to the identification of the optimal tumor antigens. At the same time, the development of appropriate delivery strategies, adjuvants, and combination therapies to counteract the immunosuppressive tumor microenvironment will ultimately provide the sought improvement in the clinical outcome of cancer patients.

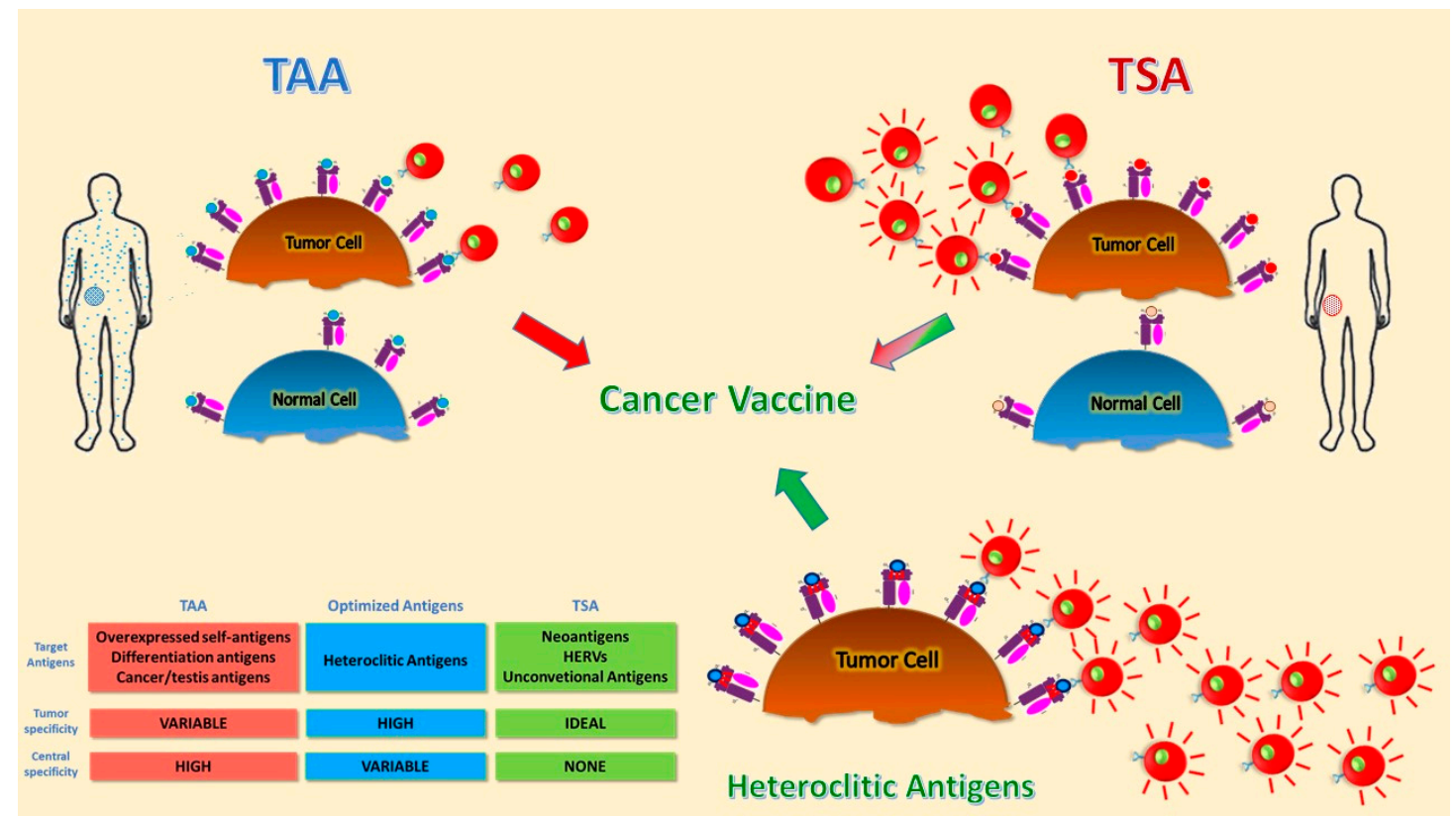

Figure 1. Schematic representation of different tumor antigens. Targets for tumor vaccines fall into tumor-associated antigens (TAAs) and tumor-specific antigens (TSAs). TAAs are self-antigens that are either preferentially or abnormally expressed in tumor cells, but may be expressed at some level in normal cells as well. T cells that bind with high affinity to TAAs are low in number because they are deleted by central and peripheral tolerance mechanisms. Heteroclitic peptides are modified TAAs able to break tolerance and induce a more potent $\mathrm{T}$ cell response. TSAs include antigens encoded only by cancer cells and are truly tumor-specific, eliciting high-affinity T cells. Different colors indicate the difference between antigens presented by normal and tumor cells. The red-lines on $\mathrm{T}$ cells indicate more activated and tumor-specific cells.

Author Contributions: Writing—original draft preparation, M.T.; writing-review and editing, L.B.; supervision, L.B. All authors have read and agreed to the published version of the manuscript.

Funding: This research was funded by ERANET-TRANSCAN-2 within HORIZON 2020, grant number TRS-2016-00000383: www.hepamut.eu.

Conflicts of Interest: The authors declare no conflict of interest.

\section{References}

1. Melero, I.; Gaudernack, G.; Gerritsen, W.; Huber, C.; Parmiani, G.; Scholl, S.; Thatcher, N.; Wagstaff, J.; Zielinski, C.; Faulkner, I.; et al. Therapeutic vaccines for cancer: An overview of clinical trials. Nat. Rev. Clin. Oncol. 2014, 11, 509-524. [CrossRef] [PubMed]

2. Pol, J.; Bloy, N.; Buque, A.; Eggermont, A.; Cremer, I.; Sautes-Fridman, C.; Galon, J.; Tartour, E.; Zitvogel, L.; Kroemer, G.; et al. Trial Watch: Peptide-based anticancer vaccines. Oncoimmunology 2015, 4, e974411. [CrossRef] [PubMed]

3. Melief, C.J.; van, H.T.; Arens, R.; Ossendorp, F.; van der Burg, S.H. Therapeutic cancer vaccines. J. Clin. Investig. 2015, 125, 3401-3412. [CrossRef] 
4. Tran, T.; Blanc, C.; Granier, C.; Saldmann, A.; Tanchot, C.; Tartour, E. Therapeutic cancer vaccine: Building the future from lessons of the past. Semin. Immunopathol. 2019, 41, 69-85. [CrossRef] [PubMed]

5. Kantoff, P.W.; Higano, C.S.; Shore, N.D.; Berger, E.R.; Small, E.J.; Penson, D.F.; Redfern, C.H.; Ferrari, A.C.; Dreicer, R.; Sims, R.B.; et al. Sipuleucel-T immunotherapy for castration-resistant prostate cancer. N. Engl. J. Med. 2010, 363, 411-422. [CrossRef]

6. FDA. Highlights of Prescribing Information; FDA: Rockville, MD, USA, 2010.

7. Van der Burg, S.H.; Arens, R.; Ossendorp, F.; van, H.T.; Melief, C.J. Vaccines for established cancer: Overcoming the challenges posed by immune evasion. Nat. Rev. Cancer 2016, 16, 219-233. [CrossRef] [PubMed]

8. Gordon, B.; Gadi, V.K. The Role of the Tumor Microenvironment in Developing Successful Therapeutic and Secondary Prophylactic Breast Cancer Vaccines. Vaccines 2020, 8, 529. [CrossRef]

9. Tagliamonte, M.; Petrizzo, A.; Tornesello, M.L.; Ciliberto, G.; Buonaguro, F.M.; Buonaguro, L. Combinatorial immunotherapy strategies for hepatocellular carcinoma. Curr. Opin. Immunol. 2016, 39, 103-113. [CrossRef]

10. Tagliamonte, M.; Mauriello, A.; Cavalluzzo, B.; Ragone, C.; Manolio, C.; Petrizzo, A.; Buonaguro, L. Tackling hepatocellular carcinoma with individual or combinatorial immunotherapy approaches. Cancer Lett. 2020, 473, 25-32. [CrossRef]

11. Tagliamonte, M.; Petrizzo, A.; Mauriello, A.; Tornesello, M.L.; Buonaguro, F.M.; Buonaguro, L. Potentiating cancer vaccine efficacy in liver cancer. Oncoimmunology 2018, 7, e1488564. [CrossRef]

12. Jiang, T.; Shi, T.; Zhang, H.; Hu, J.; Song, Y.; Wei, J.; Ren, S.; Zhou, C. Tumor neoantigens: From basic research to clinical applications. J. Hematol. Oncol. 2019, 12, 93. [CrossRef]

13. Tagliamonte, M.; Petrizzo, A.; Tornesello, M.L.; Buonaguro, F.M.; Buonaguro, L. Antigen-specific vaccines for cancer treatment. Hum. Vaccin. Immunother. 2014, 10, 3332-3346. [CrossRef]

14. Chiang, C.L.; Coukos, G.; Kandalaft, L.E. Whole Tumor Antigen Vaccines: Where Are We? Vaccines 2015, 3, 344-372. [CrossRef] [PubMed]

15. Keenan, B.P.; Jaffee, E.M. Whole cell vaccines-Past progress and future strategies. Semin. Oncol. 2012, 39, 276-286. [CrossRef]

16. Chiang, C.L.; Benencia, F.; Coukos, G. Whole tumor antigen vaccines. Semin. Immunol. 2010, 22, $132-143$. [CrossRef]

17. Hollingsworth, R.E.; Jansen, K. Turning the corner on therapeutic cancer vaccines. NPJ Vaccines 2019, 4, 7. [CrossRef]

18. Vonderheide, R.H.; Hahn, W.C.; Schultze, J.L.; Nadler, L.M. The telomerase catalytic subunit is a widely expressed tumor-associated antigen recognized by cytotoxic T lymphocytes. Immunity 1999, 10, 673-679. [CrossRef]

19. Disis, M.L.; Wallace, D.R.; Gooley, T.A.; Dang, Y.; Slota, M.; Lu, H.; Coveler, A.L.; Childs, J.S.; Higgins, D.M.; Fintak, P.A.; et al. Concurrent trastuzumab and HER2/neu-specific vaccination in patients with metastatic breast cancer. J. Clin. Oncol. 2009, 27, 4685-4692. [CrossRef] [PubMed]

20. Chang, K.; Pastan, I. Molecular cloning of mesothelin, a differentiation antigen present on mesothelium, mesotheliomas, and ovarian cancers. Proc. Natl. Acad. Sci. USA 1996, 93, 136-140. [CrossRef]

21. Finn, O.J.; Gantt, K.R.; Lepisto, A.J.; Pejawar-Gaddy, S.; Xue, J.; Beatty, P.L. Importance of MUC1 and spontaneous mouse tumor models for understanding the immunobiology of human adenocarcinomas. Immunol. Res. 2011, 50, 261-268. [CrossRef]

22. Parkhurst, M.R.; Fitzgerald, E.B.; Southwood, S.; Sette, A.; Rosenberg, S.A.; Kawakami, Y. Identification of a shared HLA-A*0201-restricted T-cell epitope from the melanoma antigen tyrosinase-related protein 2 (TRP2). Cancer Res. 1998, 58, 4895-4901.

23. Correale, P.; Walmsley, K.; Nieroda, C.; Zaremba, S.; Zhu, M.; Schlom, J.; Tsang, K.Y. In vitro generation of human cytotoxic T lymphocytes specific for peptides derived from prostate-specific antigen. J. Natl. Cancer Inst. 1997, 89, 293-300. [CrossRef]

24. Lam, K.W.; Li, C.Y.; Yam, L.T.; Sun, T.; Lee, G.; Ziesmer, S. Improved immunohistochemical detection of prostatic acid phosphatase by a monoclonal antibody. Prostate 1989, 15, 13-21. [CrossRef] [PubMed]

25. De, S.C.; Lurquin, C.; van der Bruggen, P.; De, P.E.; Brasseur, F.; Boon, T. Sequence and expression pattern of the human MAGE2 gene. Immunogenetics 1994, 39, 121-129. 
26. Gnjatic, S.; Cao, Y.; Reichelt, U.; Yekebas, E.F.; Nolker, C.; Marx, A.H.; Erbersdobler, A.; Nishikawa, H.; Hildebrandt, Y.; Bartels, K.; et al. NY-CO-58/KIF2C is overexpressed in a variety of solid tumors and induces frequent $\mathrm{T}$ cell responses in patients with colorectal cancer. Int. J. Cancer 2010, 127, 381-393. [CrossRef] [PubMed]

27. Hofmann, O.; Caballero, O.L.; Stevenson, B.J.; Chen, Y.T.; Cohen, T.; Chua, R.; Maher, C.A.; Panji, S.; Schaefer, U.; Kruger, A.; et al. Genome-wide analysis of cancer/testis gene expression. Proc. Natl. Acad. Sci. USA 2008, 105, 20422-20427. [CrossRef] [PubMed]

28. Simpson, A.J.; Caballero, O.L.; Jungbluth, A.; Chen, Y.T.; Old, L.J. Cancer/testis antigens, gametogenesis and cancer. Nat. Rev. Cancer 2005, 5, 615-625. [CrossRef] [PubMed]

29. Karbach, J.; Neumann, A.; Atmaca, A.; Wahle, C.; Brand, K.; von, B.L.; Knuth, A.; Bender, A.; Ritter, G.; Old, L.J.; et al. Efficient in vivo priming by vaccination with recombinant NY-ESO-1 protein and CpG in antigen naive prostate cancer patients. Clin. Cancer Res. 2011, 17, 861-870. [CrossRef]

30. Buonaguro, L.; Petrizzo, A.; Tornesello, M.L.; Buonaguro, F.M. Translating tumor antigens into cancer vaccines. Clin. Vaccine Immunol. 2011, 18, 23-34. [CrossRef]

31. Dudley, M.E.; Wunderlich, J.R.; Robbins, P.F.; Yang, J.C.; Hwu, P.; Schwartzentruber, D.J.; Topalian, S.L.; Sherry, R.; Restifo, N.P.; Hubicki, A.M.; et al. Cancer regression and autoimmunity in patients after clonal repopulation with antitumor lymphocytes. Science 2002, 298, 850-854. [CrossRef]

32. Theobald, M.; Biggs, J.; Hernandez, J.; Lustgarten, J.; Labadie, C.; Sherman, L.A. Tolerance to p53 by A2.1-restricted cytotoxic T lymphocytes. J. Exp. Med. 1997, 185, 833-841. [CrossRef] [PubMed]

33. Parmiani, G.; Castelli, C.; Dalerba, P.; Mortarini, R.; Rivoltini, L.; Marincola, F.M.; Anichini, A. Cancer immunotherapy with peptide-based vaccines: What have we achieved? Where are we going? J. Natl. Cancer Inst. 2002, 94, 805-818. [CrossRef] [PubMed]

34. Fratta, E.; Coral, S.; Covre, A.; Parisi, G.; Colizzi, F.; Danielli, R.; Nicolay, H.J.; Sigalotti, L.; Maio, M. The biology of cancer testis antigens: Putative function, regulation and therapeutic potential. Mol. Oncol. 2011, 5, 164-182. [CrossRef] [PubMed]

35. Pilla, L.; Ferrone, S.; Maccalli, C. Methods for improving the immunogenicity and efficacy of cancer vaccines. Expert. Opin. Biol. Ther. 2018, 18, 765-784. [CrossRef] [PubMed]

36. Rosenberg, S.A.; Sherry, R.M.; Morton, K.E.; Scharfman, W.J.; Yang, J.C.; Topalian, S.L.; Royal, R.E.; Kammula, U.; Restifo, N.P.; Hughes, M.S.; et al. Tumor progression can occur despite the induction of very high levels of self/tumor antigen-specific CD8+ T cells in patients with melanoma. J. Immunol. 2005, 175, 6169-6176. [CrossRef]

37. Buonaguro, L. Developments in cancer vaccines for hepatocellular carcinoma. Cancer Immunol. Immunother. 2016, 65, 93-99. [CrossRef]

38. Buonaguro, L. New vaccination strategies in liver cancer. Cytokine Growth Factor Rev. 2017, 36, $125-129$. [CrossRef]

39. Mittendorf, E.A.; Lu, B.; Melisko, M.; Price, H.J.; Bondarenko, I.; Brunt, A.M.; Sergii, G.; Petrakova, K.; Peoples, G.E. Efficacy and Safety Analysis of Nelipepimut-S Vaccine to Prevent Breast Cancer Recurrence: A Randomized, Multicenter, Phase III Clinical Trial. Clin. Cancer Res. 2019, 25, 4248-4254. [CrossRef]

40. Hodi, F.S.; O’Day, S.J.; McDermott, D.F.; Weber, R.W.; Sosman, J.A.; Haanen, J.B.; Gonzalez, R.; Robert, C.; Schadendorf, D.; Hassel, J.C.; et al. Improved survival with ipilimumab in patients with metastatic melanoma. N. Engl. J. Med. 2010, 363, 711-723. [CrossRef]

41. Schwartzentruber, D.J.; Lawson, D.H.; Richards, J.M.; Conry, R.M.; Miller, D.M.; Treisman, J.; Gailani, F.; Riley, L.; Conlon, K.; Pockaj, B.; et al. gp100 peptide vaccine and interleukin-2 in patients with advanced melanoma. N. Engl. J. Med. 2011, 364, 2119-2127. [CrossRef]

42. Vigneron, N. Human Tumor Antigens and Cancer Immunotherapy. Biomed. Res. Int. 2015, $2015,948501$. [CrossRef] [PubMed]

43. Rooney, M.S.; Shukla, S.A.; Wu, C.J.; Getz, G.; Hacohen, N. Molecular and genetic properties of tumors associated with local immune cytolytic activity. Cell 2015, 160, 48-61. [CrossRef]

44. Schumacher, T.N.; Scheper, W.; Kvistborg, P. Cancer Neoantigens. Annu. Rev. Immunol. 2019, 37, $173-200$. [CrossRef]

45. Kim, J.Y.; Kronbichler, A.; Eisenhut, M.; Hong, S.H.; van der Vliet, H.J.; Kang, J.; Shin, J.I.; Gamerith, G. Tumor Mutational Burden and Efficacy of Immune Checkpoint Inhibitors: A Systematic Review and Meta-Analysis. Cancers 2019, 11, 1798. [CrossRef] 
46. Giannakis, M.; Mu, X.J.; Shukla, S.A.; Qian, Z.R.; Cohen, O.; Nishihara, R.; Bahl, S.; Cao, Y.; Amin-Mansour, A.; Yamauchi, M.; et al. Genomic Correlates of Immune-Cell Infiltrates in Colorectal Carcinoma. Cell Rep. 2016, 17, 1206. [CrossRef]

47. Matsushita, H.; Sato, Y.; Karasaki, T.; Nakagawa, T.; Kume, H.; Ogawa, S.; Homma, Y.; Kakimi, K. Neoantigen Load, Antigen Presentation Machinery, and Immune Signatures Determine Prognosis in Clear Cell Renal Cell Carcinoma. Cancer Immunol. Res. 2016, 4, 463-471. [CrossRef] [PubMed]

48. Luen, S.; Virassamy, B.; Savas, P.; Salgado, R.; Loi, S. The genomic landscape of breast cancer and its interaction with host immunity. Breast 2016, 29, 241-250. [CrossRef] [PubMed]

49. Choudhury, N.J.; Kiyotani, K.; Yap, K.L.; Campanile, A.; Antic, T.; Yew, P.Y.; Steinberg, G.; Park, J.H.; Nakamura, Y.; O’Donnell, P.H. Low T-cell Receptor Diversity, High Somatic Mutation Burden, and High Neoantigen Load as Predictors of Clinical Outcome in Muscle-invasive Bladder Cancer. Eur. Urol. Focus. 2016, 2, 445-452. [CrossRef]

50. Feng, L.; Qian, H.; Yu, X.; Liu, K.; Xiao, T.; Zhang, C.; Kuang, M.; Cheng, S.; Li, X.; Wan, J.; et al. Heterogeneity of tumor-infiltrating lymphocytes ascribed to local immune status rather than neoantigens by multi-omics analysis of glioblastoma multiforme. Sci. Rep. 2017, 7, 6968. [CrossRef]

51. Rizvi, N.A.; Hellmann, M.D.; Snyder, A.; Kvistborg, P.; Makarov, V.; Havel, J.J.; Lee, W.; Yuan, J.; Wong, P.; Ho, T.S.; et al. Cancer immunology. Mutational landscape determines sensitivity to PD-1 blockade in non-small cell lung cancer. Science 2015, 348, 124-128. [CrossRef] [PubMed]

52. Snyder, A.; Makarov, V.; Merghoub, T.; Yuan, J.; Zaretsky, J.M.; Desrichard, A.; Walsh, L.A.; Postow, M.A.; Wong, P.; Ho, T.S.; et al. Genetic basis for clinical response to CTLA-4 blockade in melanoma. N. Engl. J. Med. 2014, 371, 2189-2199. [CrossRef]

53. Mauriello, A.; Zeuli, R.; Cavalluzzo, B.; Petrizzo, A.; Tornesello, M.L.; Buonaguro, F.M.; Ceccarelli, M.; Tagliamonte, M.; Buonaguro, L. High Somatic Mutation and Neoantigen Burden Do Not Correlate with Decreased Progression-Free Survival in HCC Patients not Undergoing Immunotherapy. Cancers 2019, 11, 1824. [CrossRef] [PubMed]

54. Stronen, E.; Toebes, M.; Kelderman, S.; van Buuren, M.M.; Yang, W.; van, R.N.; Donia, M.; Boschen, M.L.; Lund-Johansen, F.; Olweus, J.; et al. Targeting of cancer neoantigens with donor-derived T cell receptor repertoires. Science 2016, 352, 1337-1341. [CrossRef]

55. Ott, P.A.; Hu, Z.; Keskin, D.B.; Shukla, S.A.; Sun, J.; Bozym, D.J.; Zhang, W.; Luoma, A.; Giobbie-Hurder, A.; Peter, L.; et al. An immunogenic personal neoantigen vaccine for patients with melanoma. Nature 2017, 547, 217-221. [CrossRef]

56. Sahin, U.; Derhovanessian, E.; Miller, M.; Kloke, B.P.; Simon, P.; Lower, M.; Bukur, V.; Tadmor, A.D.; Luxemburger, U.; Schrors, B.; et al. Personalized RNA mutanome vaccines mobilize poly-specific therapeutic immunity against cancer. Nature 2017, 547, 222-226. [CrossRef]

57. Hilf, N.; Kuttruff-Coqui, S.; Frenzel, K.; Bukur, V.; Stevanovic, S.; Gouttefangeas, C.; Platten, M.; Tabatabai, G.; Dutoit, V.; van der Burg, S.H.; et al. Actively personalized vaccination trial for newly diagnosed glioblastoma. Nature 2019, 565, 240-245. [CrossRef] [PubMed]

58. Clinical Study of A Personalized Neoantigen Cancer Vaccine in Treating Patients with Advanced Malignant Tumor. Available online: https://cancerres.aacrjournals.org/content/79/13_Supplement/CT006 (accessed on 16 October 2020).

59. Clinical Study of Personalized Neoantigen-Based Cancer Vaccine in The Treatment of Advanced SCLC Patients with Brain Metastasis: A Case Report. Available online: https:/cancerres.aacrjournals.org/content/ 79/13_Supplement/4096 (accessed on 16 October 2020).

60. The Personalized Vaccine, NEO-PV-01 with anti-PD1, Induces Neoantigen-Specific De Novo Immune Responses in Patients with Advanced Metastatic Melanoma: Association with Clinical Outcomes. Available online: https://cancerres.aacrjournals.org/content/79/13_Supplement/942 (accessed on 16 October 2020).

61. Johnson, W.E. Origins and evolutionary consequences of ancient endogenous retroviruses. Nat. Rev. Microbiol. 2019, 17, 355-370. [CrossRef]

62. Attermann, A.S.; Bjerregaard, A.M.; Saini, S.K.; Gronbaek, K.; Hadrup, S.R. Human endogenous retroviruses and their implication for immunotherapeutics of cancer. Ann. Oncol. 2018, 29, 2183-2191. [CrossRef]

63. Jones, P.A.; Ohtani, H.; Chakravarthy, A.; De Carvalho, D.D. Epigenetic therapy in immune-oncology. Nat. Rev. Cancer 2019, 19, 151-161. [CrossRef] [PubMed] 
64. Suraweera, A.; O'Byrne, K.J.; Richard, D.J. Combination Therapy With Histone Deacetylase Inhibitors (HDACi) for the Treatment of Cancer: Achieving the Full Therapeutic Potential of HDACi. Front. Oncol. 2018, 8, 92. [CrossRef]

65. Brocks, D.; Schmidt, C.R.; Daskalakis, M.; Jang, H.S.; Shah, N.M.; Li, D.; Li, J.; Zhang, B.; Hou, Y.; Laudato, S.; et al. DNMT and HDAC inhibitors induce cryptic transcription start sites encoded in long terminal repeats. Nat. Genet. 2017, 49, 1052-1060. [CrossRef]

66. Roulois, D.; Loo, Y.H.; Singhania, R.; Wang, Y.; Danesh, A.; Shen, S.Y.; Han, H.; Liang, G.; Jones, P.A.; Pugh, T.J.; et al. DNA-Demethylating Agents Target Colorectal Cancer Cells by Inducing Viral Mimicry by Endogenous Transcripts. Cell 2015, 162, 961-973. [CrossRef]

67. Chiappinelli, K.B.; Strissel, P.L.; Desrichard, A.; Li, H.; Henke, C.; Akman, B.; Hein, A.; Rote, N.S.; Cope, L.M.; Snyder, A.; et al. Inhibiting DNA Methylation Causes an Interferon Response in Cancer via dsRNA Including Endogenous Retroviruses. Cell 2015, 162, 974-986. [CrossRef] [PubMed]

68. Kassiotis, G.; Stoye, J.P. Immune responses to endogenous retroelements: Taking the bad with the good. Nat. Rev. Immunol. 2016, 16, 207-219. [CrossRef] [PubMed]

69. Keskinen, P.; Ronni, T.; Matikainen, S.; Lehtonen, A.; Julkunen, I. Regulation of HLA class I and II expression by interferons and influenza A virus in human peripheral blood mononuclear cells. Immunology 1997, 91, 421-429. [CrossRef]

70. Snell, L.M.; McGaha, T.L.; Brooks, D.G. Type I Interferon in Chronic Virus Infection and Cancer. Trends Immunol. 2017, 38, 542-557. [CrossRef] [PubMed]

71. Neukirch, L.; Nielsen, T.K.; Laursen, H.; Daradoumis, J.; Thirion, C.; Holst, P.J. Adenovirus based virus-like-vaccines targeting endogenous retroviruses can eliminate growing colorectal cancers in mice. Oncotarget 2019, 10, 1458-1472. [CrossRef]

72. Sacha, J.B.; Kim, I.J.; Chen, L.; Ullah, J.H.; Goodwin, D.A.; Simmons, H.A.; Schenkman, D.I.; von, P.F.; Gifford, R.J.; Nimityongskul, F.A.; et al. Vaccination with cancer- and HIV infection-associated endogenous retrotransposable elements is safe and immunogenic. J. Immunol. 2012, 189, 1467-1479. [CrossRef]

73. Kraus, B.; Fischer, K.; Buchner, S.M.; Wels, W.S.; Lower, R.; Sliva, K.; Schnierle, B.S. Vaccination directed against the human endogenous retrovirus-K envelope protein inhibits tumor growth in a murine model system. PLoS ONE 2013, 8, e72756. [CrossRef]

74. Kraus, B.; Fischer, K.; Sliva, K.; Schnierle, B.S. Vaccination directed against the human endogenous retrovirus-K (HERV-K) gag protein slows HERV-K gag expressing cell growth in a murine model system. Virol. J. 2014, 11, 58. [CrossRef]

75. Krishnamurthy, J.; Rabinovich, B.A.; Mi, T.; Switzer, K.C.; Olivares, S.; Maiti, S.N.; Plummer, J.B.; Singh, H.; Kumaresan, P.R.; Huls, H.M.; et al. Genetic Engineering of T Cells to Target HERV-K, an Ancient Retrovirus on Melanoma. Clin. Cancer Res. 2015, 21, 3241-3251. [CrossRef] [PubMed]

76. Zhou, F.; Krishnamurthy, J.; Wei, Y.; Li, M.; Hunt, K.; Johanning, G.L.; Cooper, L.J.; Wang-Johanning, F. Chimeric antigen receptor $\mathrm{T}$ cells targeting HERV-K inhibit breast cancer and its metastasis through downregulation of Ras. Oncoimmunology 2015, 4, e1047582. [CrossRef]

77. Aebersold, R.; Mann, M. Mass spectrometry-based proteomics. Nature 2003, 422, 198-207. [CrossRef] [PubMed]

78. Alfaro, J.A.; Ignatchenko, A.; Ignatchenko, V.; Sinha, A.; Boutros, P.C.; Kislinger, T. Detecting protein variants by mass spectrometry: A comprehensive study in cancer cell-lines. Genome Med. 2017, 9, 62. [CrossRef] [PubMed]

79. Lobas, A.A.; Pyatnitskiy, M.A.; Chernobrovkin, A.L.; Ilina, I.Y.; Karpov, D.S.; Solovyeva, E.M.; Kuznetsova, K.G.; Ivanov, M.V.; Lyssuk, E.Y.; Kliuchnikova, A.A.; et al. Proteogenomics of Malignant Melanoma Cell Lines: The Effect of Stringency of Exome Data Filtering on Variant Peptide Identification in Shotgun Proteomics. J. Proteome. Res. 2018, 17, 1801-1811. [CrossRef]

80. Wang, X.; Slebos, R.J.; Wang, D.; Halvey, P.J.; Tabb, D.L.; Liebler, D.C.; Zhang, B. Protein identification using customized protein sequence databases derived from RNA-Seq data. J. Proteome. Res. 2012, 11, 1009-1017. [CrossRef] [PubMed]

81. Yadav, M.; Jhunjhunwala, S.; Phung, Q.T.; Lupardus, P.; Tanguay, J.; Bumbaca, S.; Franci, C.; Cheung, T.K.; Fritsche, J.; Weinschenk, T.; et al. Predicting immunogenic tumour mutations by combining mass spectrometry and exome sequencing. Nature 2014, 515, 572-576. [CrossRef] 
82. Zhang, B.; Wang, J.; Wang, X.; Zhu, J.; Liu, Q.; Shi, Z.; Chambers, M.C.; Zimmerman, L.J.; Shaddox, K.F.; Kim, S.; et al. Proteogenomic characterization of human colon and rectal cancer. Nature 2014, 513, 382-387. [CrossRef]

83. Mertins, P.; Mani, D.R.; Ruggles, K.V.; Gillette, M.A.; Clauser, K.R.; Wang, P.; Wang, X.; Qiao, J.W.; Cao, S.; Petralia, F.; et al. Proteogenomics connects somatic mutations to signalling in breast cancer. Nature 2016, 534, 55-62. [CrossRef]

84. Johansson, H.J.; Socciarelli, F.; Vacanti, N.M.; Haugen, M.H.; Zhu, Y.; Siavelis, I.; Fernandez-Woodbridge, A.; Aure, M.R.; Sennblad, B.; Vesterlund, M.; et al. Breast cancer quantitative proteome and proteogenomic landscape. Nat. Commun. 2019, 10, 1600. [CrossRef]

85. Zhang, H.; Liu, T.; Zhang, Z.; Payne, S.H.; Zhang, B.; McDermott, J.E.; Zhou, J.Y.; Petyuk, V.A.; Chen, L.; Ray, D.; et al. Integrated Proteogenomic Characterization of Human High-Grade Serous Ovarian Cancer. Cell 2016, 166, 755-765. [CrossRef]

86. Gao, Q.; Zhu, H.; Dong, L.; Shi, W.; Chen, R.; Song, Z.; Huang, C.; Li, J.; Dong, X.; Zhou, Y.; et al. Integrated Proteogenomic Characterization of HBV-Related Hepatocellular Carcinoma. Cell 2019, 179, 561-577. [CrossRef]

87. Vigneron, N.; Ferrari, V.; Stroobant, V.; Abi, H.J.; Van den Eynde, B.J. Peptide splicing by the proteasome. J. Biol. Chem. 2017, 292, 21170-21179. [CrossRef] [PubMed]

88. Liepe, J.; Marino, F.; Sidney, J.; Jeko, A.; Bunting, D.E.; Sette, A.; Kloetzel, P.M.; Stumpf, M.P.; Heck, A.J.; Mishto, M. A large fraction of HLA class I ligands are proteasome-generated spliced peptides. Science 2016, 354, 354-358. [CrossRef] [PubMed]

89. Faridi, P.; Li, C.; Ramarathinam, S.H.; Vivian, J.P.; Illing, P.T.; Mifsud, N.A.; Ayala, R.; Song, J.; Gearing, L.J.; Hertzog, P.J.; et al. A subset of HLA-I peptides are not genomically templated: Evidence for cis- and trans-spliced peptide ligands. Sci. Immunol. 2018, 3, eaar3947. [CrossRef]

90. Hanada, K.; Yewdell, J.W.; Yang, J.C. Immune recognition of a human renal cancer antigen through post-translational protein splicing. Nature 2004, 427, 252-256. [CrossRef]

91. Ingolia, N.T. Ribosome Footprint Profiling of Translation throughout the Genome. Cell 2016, 165, $22-33$. [CrossRef]

92. Boon, T.; Van, P.A. T cell-recognized antigenic peptides derived from the cellular genome are not protein degradation products but can be generated directly by transcription and translation of short subgenic regions. A hypothesis. Immunogenetics 1989, 29, 75-79. [CrossRef]

93. Laumont, C.M.; Vincent, K.; Hesnard, L.; Audemard, E.; Bonneil, E.; Laverdure, J.P.; Gendron, P.; Courcelles, M.; Hardy, M.P.; Cote, C.; et al. Noncoding regions are the main source of targetable tumor-specific antigens. Sci. Transl. Med. 2018, 10, eaau5516. [CrossRef] [PubMed]

94. Kanaseki, T.; Torigoe, T. Proteogenomics: Advances in cancer antigen research. Immunol. Med. 2019, 42, 65-70. [CrossRef]

95. Fikes, J.D.; Sette, A. Design of multi-epitope, analogue-based cancer vaccines. Expert. Opin. Biol. Ther. 2003, 3, 985-993. [CrossRef] [PubMed]

96. Carrabba, M.G.; Castelli, C.; Maeurer, M.J.; Squarcina, P.; Cova, A.; Pilla, L.; Renkvist, N.; Parmiani, G.; Rivoltini, L. Suboptimal activation of CD8(+) T cells by melanoma-derived altered peptide ligands: Role of Melan-A/MART-1 optimized analogues. Cancer Res. 2003, 63, 1560-1567.

97. Parkhurst, M.R.; Salgaller, M.L.; Southwood, S.; Robbins, P.F.; Sette, A.; Rosenberg, S.A.; Kawakami, Y. Improved induction of melanoma-reactive CTL with peptides from the melanoma antigen gp100 modified at HLA-A*0201-binding residues. J. Immunol. 1996, 157, 2539-2548. [PubMed]

98. Chen, J.L.; Dunbar, P.R.; Gileadi, U.; Jager, E.; Gnjatic, S.; Nagata, Y.; Stockert, E.; Panicali, D.L.; Chen, Y.T.; Knuth, A.; et al. Identification of NY-ESO-1 peptide analogues capable of improved stimulation of tumor-reactive CTL. J. Immunol. 2000, 165, 948-955. [CrossRef] [PubMed]

99. Dao, T.; Korontsvit, T.; Zakhaleva, V.; Jarvis, C.; Mondello, P.; Oh, C.; Scheinberg, D.A. An immunogenic WT1-derived peptide that induces T cell response in the context of HLA-A*02:01 and HLA-A*24:02 molecules. Oncoimmunology 2017, 6, e1252895. [CrossRef]

100. Bae, J.; Samur, M.; Munshi, A.; Hideshima, T.; Keskin, D.; Kimmelman, A.; Lee, A.H.; Dranoff, G.; Anderson, K.C.; Munshi, N.C. Heteroclitic XBP1 peptides evoke tumor-specific memory cytotoxic T lymphocytes against breast cancer, colon cancer, and pancreatic cancer cells. Oncoimmunology 2014, 3, e970914. [CrossRef] 
101. Birnbaum, M.E.; Mendoza, J.L.; Sethi, D.K.; Dong, S.; Glanville, J.; Dobbins, J.; Ozkan, E.; Davis, M.M.; Wucherpfennig, K.W.; Garcia, K.C. Deconstructing the peptide-MHC specificity of T cell recognition. Cell 2014, 157, 1073-1087. [CrossRef]

102. Stone, J.D.; Chervin, A.S.; Kranz, D.M. T-cell receptor binding affinities and kinetics: Impact on T-cell activity and specificity. Immunology 2009, 126, 165-176. [CrossRef]

103. Hawse, W.F.; De, S.; Greenwood, A.I.; Nicholson, L.K.; Zajicek, J.; Kovrigin, E.L.; Kranz, D.M.; Garcia, K.C.; Baker, B.M. TCR scanning of peptide/MHC through complementary matching of receptor and ligand molecular flexibility. J. Immunol. 2014, 192, 2885-2891. [CrossRef]

104. Madura, F.; Rizkallah, P.J.; Holland, C.J.; Fuller, A.; Bulek, A.; Godkin, A.J.; Schauenburg, A.J.; Cole, D.K.; Sewell, A.K. Structural basis for ineffective T-cell responses to MHC anchor residue-improved "heteroclitic" peptides. Eur. J. Immunol. 2015, 45, 584-591. [CrossRef]

105. Dyson, J. T-cell receptors: Tugging on the anchor for a tighter hold on the tumor-associated peptide. Eur. J. Immunol. 2015, 45, 380-382. [CrossRef] [PubMed]

106. Rosenberg, S.A.; Yang, J.C.; Schwartzentruber, D.J.; Hwu, P.; Marincola, F.M.; Topalian, S.L.; Restifo, N.P.; Dudley, M.E.; Schwarz, S.L.; Spiess, P.J.; et al. Immunologic and therapeutic evaluation of a synthetic peptide vaccine for the treatment of patients with metastatic melanoma. Nat. Med. 1998, 4, 321-327. [CrossRef] [PubMed]

107. Sosman, J.A.; Carrillo, C.; Urba, W.J.; Flaherty, L.; Atkins, M.B.; Clark, J.I.; Dutcher, J.; Margolin, K.A.; Mier, J.; Gollob, J.; et al. Three phase II cytokine working group trials of gp100 (210M) peptide plus high-dose interleukin-2 in patients with HLA-A2-positive advanced melanoma. J. Clin. Oncol. 2008, 26, 2292-2298. [CrossRef] [PubMed]

108. Tsang, K.Y.; Zhu, M.; Nieroda, C.A.; Correale, P.; Zaremba, S.; Hamilton, J.M.; Cole, D.; Lam, C.; Schlom, J. Phenotypic stability of a cytotoxic T-cell line directed against an immunodominant epitope of human carcinoembryonic antigen. Clin. Cancer Res. 1997, 3, 2439-2449. [PubMed]

109. Zaremba, S.; Barzaga, E.; Zhu, M.; Soares, N.; Tsang, K.Y.; Schlom, J. Identification of an enhancer agonist cytotoxic T lymphocyte peptide from human carcinoembryonic antigen. Cancer Res. 1997, 57, 4570-4577.

110. Binkowski, T.A.; Marino, S.R.; Joachimiak, A. Predicting HLA class I non-permissive amino acid residues substitutions. PLoS ONE 2012, 7, e41710. [CrossRef] [PubMed]

111. Moise, L.; Gutierrez, A.H.; Bailey-Kellogg, C.; Terry, F.; Leng, Q.; Abdel Hady, K.M.; VerBerkmoes, N.C.; Sztein, M.B.; Losikoff, P.T.; Martin, W.D.; et al. The two-faced T cell epitope: Examining the host-microbe interface with JanusMatrix. Hum. Vaccin. Immunother. 2013, 9, 1577-1586. [CrossRef] [PubMed]

112. Capasso, C.; Magarkar, A.; Cervera-Carrascon, V.; Fusciello, M.; Feola, S.; Muller, M.; Garofalo, M.; Kuryk, L.; Tahtinen, S.; Pastore, L.; et al. A novel in silico framework to improve MHC-I epitopes and break the tolerance to melanoma. Oncoimmunology 2017, 6, e1319028. [CrossRef]

Publisher's Note: MDPI stays neutral with regard to jurisdictional claims in published maps and institutional affiliations.

(C) 2020 by the authors. Licensee MDPI, Basel, Switzerland. This article is an open access article distributed under the terms and conditions of the Creative Commons Attribution (CC BY) license (http://creativecommons.org/licenses/by/4.0/). 